\title{
Human Resource Management, Individualism-Collectivism, and Individual Performance among Public Employees: A Test of the Main and Moderating Effects*
}

\author{
Taejun Cho** and Sujae Yoon***
}

\begin{abstract}
Two hundred fifteen public employees participated in this study, which tested the relationship between innovative human resources management (HRM) practices-including training, career development, appraisal feedback, participation in decision-making, and autonomy - and individual performance. This study found that almost all HRM practices were positively related to individual performance, with the exception of career development. These findings suggest that HRM practices may be a managerial strategy to increase individual performance in public sector organizations. Further, the study examined the moderating effect of individualism-collectivism on the relationship between HRM practices and individual performance. Consistent with the hypothesis, individualism-collectivism moderated the relationship between HRM practices and individual performance.
\end{abstract}

Keywords: Innovative Human Resource Management Practices, IndividualismCollectivism, Individual Performance

* The first draft of this paper was presented at the 2005 annual meeting of SECoPA in Little Rock, Arkansas, USA.

** Taejun Cho (Ph.D., State University of New York at Albany) is associate research fellow in the Center for Organization and Future Strategy at the Korea Institute of Public Administration. His research focuses on human resource management, empowerment, and organizational citizenship behavior. Email: taejunc@kipa.re.kr.

*** Sujae Yoon (Ph.D., Chung-Ang University) is research fellow in the Headquarter for Governance Research at the Korea Institute of Public Administration. He is interested in policy analysis \& evaluation, performance management, and organization studies. Email: sjyoon@kipa.re.kr.

Manuscript received January 2009; out for review January 2009; review completed February 2009; accepted February 2009.

The Korean Journal of Policy Studies, Vol. 23, No. 2, 57-78 (2009)

(C) 2009 by the GSPA, Seoul National University 


\section{INTRODUCTION}

As managerial strategies to improve organizational outcomes, innovative human resources management (HRM) practices have been employed in the private sector. Based on the resource-based theory, which argues that human resources (HR) is a source of sustained competitive advantage (Barney 1991; Pfeffer 1994; Wright et al. 1994), organizations have invested in high-performance HR systems to improve organizational outcomes, such as productivity and efficiency (Arthur 1994; Delaney and Huselid 1996; Guthrie 2001; Huselid 1995; Huselid et al. 1997; Jackson and Schuler 1995; MacDuffie 1995). Unfortunately, public sector organizations are less likely to focus on innovative HRM practices than private ones, because public personnel administration is inherently related to rigid classification, longevity, and an adversarial relationship between labor and management (Wright and Kim 2004). In response to the trend toward new public management (NPM), which stresses market- and resultsbased approaches (Hood and Peters 2004; Lynn 2001; Selden et al. 2001; Stark 2002; Steijn 2004), public sector organizations have recently made efforts to bring in innovative HRM practices to improve productivity (Cipolla 1996). In public management, some studies have supported the view that HRM practices lead to an increase in organizational performance and in workers' satisfaction (Kim 2002; Ting 1996; Wright and Kim 2004).

Although almost all studies have reported a positive relationship between HRM practices and job satisfaction (Gould-Williams 2003; Wagner 1994), as well as organizational performance (Appelbaum and Batt 1994; Becker and Gerhart 1996; Ichniowski and Shaw 1999) in the private sector, extant studies have not considered individual performance as a major outcome of HRM practices, and this may be interesting to examine. Wright and McMahan (1992) argue that HRM practices were designed to increase individual performance, but there have been few studies to examine the relationship between the two constructs.

Additionally, scholars supporting cultural value perspective note that transferring HRM practices to different work units is a difficult task due to the misfit between different cultures (Fey and Bjorkman 2001; Ngo et al. 1998; Rosenzweig and Nohria 1994). Their basic assumption is that HRM researchers do not seriously consider the importance of cultural or contextual factors, while these differences affect HRM practices (Datta et al. 2005; Jackson and Schuler 1995). Overcoming this limitation, Miller, Bersoff, and Harwood (1990) point out the importance of culture, noting that cultural differences (e.g., individualism vs. collectivism) affect an individual's behaviors in a work unit. For example, most studies of HRM practices have been conducted in western societies, which tend to have more individualistic cultures that focus on self-reliance, 
equity, and social justice. Nevertheless, most organizations that may be classified as having collectivist cultures have attempted to introduce innovative HRM practices, which were originally developed for individually oriented organizations, without considering the differences between individualistic and collectivist cultures. Only a few studies have emphasized the importance of cultural differences in their investigation of HRM practices (Ramamoorthy and Carroll 1998). Thus, this study examines the effects of individualism-collectivism, which is understood as one dimension of the culture construct (Hofstede 1980; 1997), on the relationship between HRM practices and individual performance.

\section{THEORETICAL FRAMEWORK AND HYPOTHESES}

\section{Individual Performance}

Under the trends of NPM in public management, most researchers and practitioners have emphasized performance-oriented outcomes. Few studies have focused on individual performance, but most studies have emphasized organizational performance by arguing that almost no organizations are operated by an individual (Lawler 1992). However, some studies in the fields of industrial/organizational psychology and personnel management have stressed the importance of individual performance, because performance or work outcome can be evaluated by both personal behavior and system factors (Sonnentag and Frese 2002). In supporting the above argument, Blumberg and Pringle $(1982,562)$ note, "Traditionally personnel psychologists have assumed that performance, in large part, is a function of selection, placement, and training." Thus, individual performance is one major factor to evaluate overall performance (Carson et al. 1992).

Individual performance is defined as the function of an interactive relationship between ability (e.g., competence and knowledge) and motivation (Maier 1955). Blumberg and Pringle (1982) note that ability and motivation are understood as capacity and willingness, respectively (Parker and Turner 2002). In particular, individual performance is defined as capacity, which is "the psychological and cognitive capabilities that enable an individual to perform a task effectively" (Blumberg and Pringle 1982, 563). It can also be briefly defined as the knowledge and skills needed to accomplish one's work. Willingness, as another dimension of individual performance, is defined as "the psychological and emotional characteristics that influence the degree to which an individual is inclined to perform a task" (Blumberg and Pringle 1982, 563). As the last dimension of individual performance, an opportunity (i.e., environmental variables 
and situational constraints), which is defined as "states of nature and actions of others are combined into a general category" (Blumberg and Pringle 1982, 564), should be considered (Wall, Cordery, and Clegg 2002).

\section{Human Resources Management Practices}

HRM is defined as "the branch of organizational science that deals with the entire employment and relationship, along with all the decisions, actions, and issues involved in that relationship" (Dulebohn et al. 1995, 18). HRM practices lead to an increase in performance and satisfaction and a reduction in employee turnover and absenteeism (Huselid 1995). In particular, Rousseau (1995, 180) notes, “These practices encourage employees to develop organization-specifics skill, share cultural norms supporting good customer relations, and retain people." Based on the functions of HRM practices, most studies (Delaney and Huselid 1996; Guest 1997; Huselid 1995) have argued that HRM practices can be classified into three categories: those affecting employees' skill and ability (e.g., training-oriented programs), employees' motivation (e.g., incentive compensation), and the structure of work (e.g., employees' participation in decisionmaking). Following the extant studies' categories of HRM practices, we explore the relationship by which HRM practices-training, career development, performance appraisal, employee participation, and autonomy — affect individual performance.

\section{Training}

Organizations invest to training as a program to sustain and develop their employees' productivity (Gattiker 1995; Guthrie and Schwoerer 1994). House (1962, 76) notes that training is needed to deal with "a lack of management enthusiasm." Thus, training is defined as "a planned effort by an organization to facilitate employees' learning jobrelated behavior on the part of its employees" (Wexley and Latham 1991, 3) or "any attempt to improve current or future employee performance by increasing, through learning, an employee's ability to perform, usually by increasing his or her skills and knowledge" (Schuler 1984, 388). In sum, as a "short-term" practice (Butler et al. 1991, 132), training is designed to develop and increase employees' technical skills, administrative competence, and managerial knowledge in a relatively short time.

Based on these definitions and functions, we expect that training is one HRM practice to increase employees' willingness to commit to their organizations, improve their capacity and self-awareness, and remove managerial deficiencies (Tannenbaum et al. 1991). In supporting the above argument, Pynes $(2004,284)$ maintains that training is one HRM initiative that focuses on "improving an individual's level of self-awareness, increasing an individual's competency in one or more areas of expertise, or increasing 
an individual's motivation to perform his or her job well."

Without a doubt, investment in training is a comprehensive process that requires training at personal, organizational, and environmental levels (Goldstein 1993). Training programs may lead to a conflict between the program's contents and purpose on the one hand and the participant's personal traits and situation on the other hand (Carroll and Nash 1970). Due to these complicated issues in developing training programs, HR managers have not seriously considered the importance of training (Molander and Winterton 1994). Nonetheless, training programs have been become an important HRM practice because internal and external work environments require that front-line managers and employees must obtain advanced skills and techniques. As a result of the benefits that training provides, we expect that training positively affects individual performance.

Hypothesis 1: Training positively affects individual performance.

\section{Career Development}

Career is understood as "a lifelong process comprised of the sequence of activities and related attitudes/behaviors that take place as a person's work life unfold" (Gutteridge 1986, 53). Based on this definition, career development may be defined as "a system of processes and practices designed to link an individual employee's career goals with the organization's human resource needs" (Gutteridge et al. 1993, 12). Based on that definition, career development and training have similar functions. Like training programs, career development is also designed to provide opportunities that develop and improve administrative knowledge, skills, and technologies, to help employees to manage internal and external requirements (London and Stumpf 1986).

Nonetheless, there are two aspects that differentiate the two HRM programs. While training programs provide administrative knowledge and technologies for current positions in a work unit, career development programs are designed to provide a chance to increase employees' abilities that are expected to be needed in the future (Pynes 2004). Another reason is that training is designed to provide short-term opportunities to employees (Butler et al. 1991, 132), whereas career development is designed to provide long-term opportunities for preparing for future tasks. Although career development is different from training for these reasons, the former plays a role of increasing employees' career motivation and improving performance (Noe 1996).

Hypothesis 2: Career development positively affects individual performance. 


\section{Appraisal Feedback}

As a means of making public employees more accountable and efficient, performance appraisal - a managerial tool to evaluate employees' performance and identify their organizational missions and roles (Daley 1992; Wright and Kim 2004) — has been employed in the public sector (Perry et al. 1989; Pynes 2004). Carson et al. (1991, 143) identify it as "a necessary and effective management tool" to evaluate the employee's work variation. It is also defined as "ways for organizations to keep track of the value provided by each employee" (Shaw et al. 1998, 514). In sum, performance appraisal is identified as one HRM practice to provide feedback to employees based on an examination of their works.

Although performance appraisal is considered as a management tool to increase employee performance, it has been regarded as a problem area in HRM because it may pass over the importance of organizational factors (Bowman 1994; Lawler 1992; Murphy and Cleveland 1995). The groundwork of the critique is that performance evaluation should be based on a group's performance rather than a single individual's. That is, performance evaluation seeks to improve the use of staff resources and provide a guideline for personnel actions. In line with the above statement, group-based incentives may be an alternative to encourage employees to be concerned about their performance (Dobbins et al. 1991). Thus, an appraisal system cannot appropriately deliver benefits to organizations. Another problem is that performance ratings are subject to subjectivity and inaccuracy that disturb objective evaluation (Cardy and Dobbins 1994).

Despite these critiques, extant studies have admitted that performance appraisal leads to an increase in employees' performance and operational effectiveness (Ammons and Rodriguez 1986; Haines III et al. 2004) and in quality improvement (Armstrong and Baron 1998; Bowman 1994; Lam and Schaubroeck 1998). In supporting the positive impact of performance appraisal, Mount $(1984,271)$ note that it serves "a variety of purposes such as providing the basis for making selection decisions, determining salary increases, and providing a vehicle for feedback between supervisors and employees."

Hypothesis 3: Performance appraisal positively affects individual performance.

\section{Employee Participation in Decision-Making}

As one managerial strategy in the field of HRM, employee participation has been a major issue. Participation in decision-making may be defined as "a mode of organizational operations in which decisions as to activities are arrived at by the very persons who are to execute those decisions" (Lowin 1968, 69) or "a process in which influence 
is shared among individuals who are otherwise hierarchical unequals" (Wagner 1994, 312). Additionally, it is identified as a managerial strategy to share decision-making authority (Donald et al. 2001), or information sharing and group commitment to decisions (McCaffrey et al. 1995).

Employee participation may have a positive impact on employees' willingness to be innovative and change management (Wexley and Yukl 1984), as well as increase job satisfaction (Donald et al. 2001; Wright and Kim 2004). In particular, it also provides intrinsic personal benefits, including personal growth and development, job satisfaction, and willingness to change (Lawler and Hackman 1969). Kearney and Hays $(1994,44)$ note, "Participative decision making provides personal benefits to the individual employee as well as desired organizational outcomes." Additionally, employee participation allows workers at all levels of the organization to share information, knowledge, power, and rewards so that they can influence and be rewarded for organizational performance (Miller and Monge 1986). Thus, this study expects that it will have a positive effect on individual performance because it is a strategy to motivate employee willingness to commit to the organization, understand organizational processes, and increase technical skills for problem solving.

Hypothesis 4: Employee participation in decision-making positively affects individual performance.

\section{Autonomy}

Autonomy is defined as "the degree to which a job provides substantial freedom, independence, and discretion to the individual in scheduling the work and in determining the procedures to be used in carrying it out" (Hackman and Oldham 1975, 162) or "the job characteristic that gives employees some control over their own affairs" (Davis 1997, 239). It may be also understood as self-determination (Liden and Tewksbury 1995; Spreitzer 1995), which involves "choice in initiating and regulating one's action" (Gomez and Rosen 2001, 55) and means "the experience of choice" (Deci and Ryan 1985, 105). Quinn and Spreitzer $(1997,41)$ also note, "Empowered people are free to choose how to do their work and that they are not micro-managed." Similarly, self-determination reflects autonomy over the initiation and continuation of work behaviors and processes (Spreitzer et al. 1999) or a confidence that an individual has autonomy or control over factors that influence his or her work behaviors (Sagie and Koslowsky 2000). Thus, it is closely related to an individual's delegation, freedom, and discretion in the workplace.

Based on the literature, this study expects a positive relationship between autonomy and individual performance because employees who have managerial power and 
discretion in the processes of management should gain managerial ability, skill, and knowledge that may help increase their individual performance. Some studies have argued that autonomy is not a direct cause of increased individual performance and satisfaction (Lowin 1968; Rosenberg and Rosenstein 1980), whereas others have reported the positive relationship (Breaugh 1985; Marrow et al. 1967).

Hypothesis 5: Autonomy positively affects individual performance.

\section{Individualism-Collectivism}

As one way to compare cultural differences, Hofstede (1980) developed the dimension of individualism-collectivism, defined as follows: "individualism pertains to societies in which the ties between individuals are loose, and collectivism pertains to societies in which people from birth onwards are integrated into strong, cohesive groups" (Hofstede 1997, 113). Based on the state of group membership (i.e., in-group and outgroup membership) (Earley and Gibson 1998; Erez and Earley 1993), individualistic societies place an emphasis on personal achievement, individual freedom, independence, and equity rule, while collectivist societies emphasize interdependence, collective interests, and equality norms (Leung 1987; Triandis 1995; Triandis et al. 1990). Thus, individualism is defined as the cultural tendency that emphasizes the self as the most meaningful unit, while collectivism is defined as cultural tendency that focuses on the groups to which people belong, such as family (Triandis and Suh 2002).

While the construct of individualism-collectivism was developed to measure cultural differences in the level of society, it has been treated as an individual difference variable in recent studies (Ramamoorthy and Flood 2004). Studies that focus on individualism-collectivism at micro (e.g., personal) levels argue that individualists put an emphasis on self-interests and personal development (i.e., idiocentrism), whereas collectivists emphasize collective interests and group-based benefits (i.e., allocentrism). In particular, the former emphasizes personal achievement, equity-oriented formal reward systems, and independence from in-group membership, whereas the latter stresses collective harmony, equality-based reward systems, and interdependence with in-group members. Thus, it may be possible to expect that individuals who have different cultural orientations (e.g., toward individualism or collectivism) behave differently in a work unit. Based on the review, this study expects that individualism-collectivism can have a moderating effect on the relationship between HRM practices and individual performance, because this construct explains different cultural orientations. In particular, individualists are more likely to report a positive relationship between HRM practices and individual performance, because innovative HRM practices have been developed in western societies, which may be typically represented by individualistic 
orientations that seek self-reliance, differentiation, and competitiveness (Triandis 1995). In contrast, collectivists are less likely to report a positive relationship between HRM practices and individual performance, because they are more likely to seek interdependence and collaboration in a work unit (Workman 2001).

Hypothesis 6: Individualism-collectivism moderates the relationship between HRM practices and individual performance.

\section{METHODOLOGY}

\section{Sample}

This study focuses on employees working in government organizations in Korea, which is classified as a collectivist culture. The sampling frame was drawn from employees working in the central government. A survey instrument was administered in 18 government ministries. Twenty questionnaires were allocated to employees working in the departments of human resources and public relations in each ministry. Of the 360 distributed questionnaires, 215 usable questionnaires were returned. The response rate was 59.7 percent. Demographic information is presented in Table 1.

Table 1. Characteristics of Survey Respondents $(\mathrm{N}=215)$

\begin{tabular}{|c|c|c|}
\hline & & Percentage \\
\hline Gender & $\begin{array}{l}\text { Female } \\
\text { Male }\end{array}$ & $\begin{array}{l}21.9 \\
78.1\end{array}$ \\
\hline Age & $\begin{array}{l}\text { Less than } 29 \text { years old } \\
30 \text { through } 39 \text { years old } \\
40 \text { through } 49 \text { years old } \\
50 \text { years old or more }\end{array}$ & $\begin{array}{r}7.4 \\
35.8 \\
41.4 \\
15.3\end{array}$ \\
\hline Tenure in agency & $\begin{array}{l}\text { Less than } 6 \text { years } \\
7 \text { to } 12 \text { years } \\
13 \text { years or more }\end{array}$ & $\begin{array}{l}36.7 \\
45.1 \\
18.1\end{array}$ \\
\hline Position & $\begin{array}{l}\text { Ranks } 3 \text { to } 4 \\
\text { Rank } 5 \\
\text { Ranks } 6 \text { to } 7\end{array}$ & $\begin{array}{r}8.4 \\
63.7 \\
27.9\end{array}$ \\
\hline Education & $\begin{array}{l}\text { College } \\
\text { Bachelor's degree } \\
\text { Master's degree }\end{array}$ & $\begin{array}{c}7.4 \\
76.7 \\
15.8\end{array}$ \\
\hline Type of government ministry & $\begin{array}{l}\text { Economic/industrial ministries } \\
\text { Social/cultural ministries } \\
\text { Governance ministries }\end{array}$ & $\begin{array}{l}34.9 \\
36.7 \\
28.4\end{array}$ \\
\hline
\end{tabular}




\section{Variables}

Training was measured using four items adopted from Smith's (1995) scale (e.g., "My organization places the right amount of emphasis or importance on training"). Career development was also measured with Smith's (1995) instrument, which examined the organization's interest in career development (e.g., "My organization takes an interest in my career development or advancement") and individual development (e.g., "My organization provides me with sufficient challenge"). Appraisal feedback was measured using Nyhan's (1994) instruments to measure feedback performance (e.g., "I receive frequent and fair appraisals of my job performance by my supervisor"). Employee participation was measured by four items (e.g., "I feel involved in important decisions in my work unit") that were used in Wright and Kim's (2004) study. Autonomy was evaluated by Spreitzer's (1995) three items measuring the degree of the employee's self-determination in the workplace (e.g., "I can decide on my own how to go about doing my work"). As the moderating variable, we used the Individualism-Collectivism (I/C) Scale, ${ }^{1}$ which was developed by Ramamoorthy and Flood (2004). Finally, we adopted Heilman et al.'s (1992) two items (e.g., "I am very competent") to measure individual performance. Responses for all items in this study were measured on a seven-point scale (1, "strongly disagree," to 7, "strongly agree").

\section{Data Analysis}

Hypotheses 1 through 5 posit the effect of HRM practices on individual performance. We used multivariate regression to test this relationship. Hypothesis 6 posits that individualism-collectivism has a moderating effect on the relationship between HRM practices and individual performance, and tested it using hierarchical moderated regression analysis.

\section{RESULTS}

\section{Descriptive Statistics}

Table 2 provides descriptive statistics among the variables used in this study. An analysis of bivariate relationships found that correlations between HRM practices and individual performance were statistically significant at $p<0.05$ and $p<0.01$. This

1. On this scale, a higher score indicates a higher degree of individualism. 
means that the adoption of HRM practices in a work unit may lead to an increase in individual performance in public sector organizations. Additionally, reliability for the measures achieved an acceptable level of internal consistency (0.70).

Table 2. Descriptive Statistics

\begin{tabular}{l|c|c|c|c|c|c|c|c|c}
\hline & Mean & S.D. & 1 & 2 & 3 & 4 & 5 & 6 & 7 \\
\hline Training & 5.06 & 0.98 & $(0.91)$ & & & & & & \\
Career development & 3.75 & 1.29 & -0.10 & $(0.76)$ & & & & & \\
Appraisal feedback & 4.76 & 1.04 & 0.44 & $0.20^{\star *}$ & $(0.87)$ & & & & \\
Participation & 4.95 & 1.18 & 0.08 & $0.20^{\star \star}$ & $0.36^{\star \star}$ & $(0.87)$ & & & \\
Autonomy & 4.56 & 1.21 & $0.17^{\star}$ & $0.22^{\star *}$ & $0.38^{\star *}$ & $0.46^{\star *}$ & $(0.83)$ & & \\
Individual performance & 4.98 & 1.21 & $0.16^{\star}$ & $0.20^{\star *}$ & $0.45^{\star \star}$ & $0.43^{\star *}$ & $0.36^{*}$ & $(0.89)$ & \\
Individualism-collectivism & 4.27 & 1.38 & $0.15^{\star}$ & -0.02 & 0.00 & 0.04 & 0.08 & $0.17^{\star}$ & $(0.83)$ \\
\hline
\end{tabular}

Note: Cronbach's alpha is presented in parentheses.

\section{Tests of Hypotheses}

Table 3 presents the results of regression analysis that examined whether each HRM practice leads to an increase in individual performance to test the main effects. We found that almost all HRM practices, including training $(\beta=0.30, p<0.01)$, appraisal feedback $(\beta=0.34, p<0.01)$, participation $(\beta=0.27, p<0.01)$, and autonomy $(\beta=0.15, p<0.05)$, lead to increases in individual performance. As seen in Table 3, the standardized coefficients for training, appraisal feedback, participation, and autonomy were positive and significant. However, career development $(\beta=-0.23$, n.s. $)$ showed that its standardized coefficient was negative and statistically insignificant. With the exception of career development programs, HRM practices investigated in this study supported the hypotheses that HRM practices lead to improvement in individual performance. Thus, Hypotheses 1, 3, 4, and 5 were supported.

Table 3. Results of the Multiple Regression Equations

\begin{tabular}{l|c}
\hline & Individual performance $(\beta)$ \\
\hline Training & $0.30^{\star *}$ \\
Career development & -0.23 \\
Appraisal feedback & $0.40^{\star *}$ \\
Participation in decision making & $0.27^{\star *}$ \\
Autonomy & $0.15^{\star}$ \\
\hline
\end{tabular}

$R^{2}=0.65 ; F=4.46 ;$ Sig. $F=0.001$

${ }^{*} p<0.05 ;{ }^{* *} p<0.01$ 
We examined whether individualism-collectivism moderates the relationship between HRM practices and individual performance; Table 4 presents the results. This study supported the hypothesis that individualism-collectivism had a moderating effect on the relationship between HRM practices and individual performance: All interaction effects, including "training $\mathrm{x} I / \mathrm{C}$ " $(\beta=0.14, p<0.05)$, "appraisal feedback $\mathrm{x} \mathrm{I} / \mathrm{C}$ " $(\beta=0.16, p<0.05)$, "participation $\mathrm{x} \mathrm{I} / \mathrm{C}$ " $(\beta=0.15, p<0.05)$, and "autonomy $\mathrm{x}$ I/C" $(\beta=0.19, p<0.01)$ were positive and significant. The interaction effect between career development and individualism-collectivism was excluded because the practice had insignificant impact on individual performance in the previous analysis.

Table 4. Results of the Moderated Regression Analysis: Moderating Effects of Individualism-Collectivism

\begin{tabular}{|c|c|c|c|c|c|}
\hline & \multicolumn{5}{|c|}{ Individual performance } \\
\hline & $b$ & Std. error & $\beta$ & $\mathrm{t}$ & Sig. \\
\hline Training & 0.26 & 0.08 & 0.20 & 3.51 & $0.001^{* \star}$ \\
\hline Appraisal feedback & 0.35 & 0.07 & 0.30 & 4.89 & $0.000^{\star \star *}$ \\
\hline Participation & 0.26 & 0.07 & 0.26 & 3.99 & $0.000^{* * *}$ \\
\hline Autonomy & 0.17 & 0.07 & 0.17 & 2.64 & $0.009^{* *}$ \\
\hline $\mathrm{l} / \mathrm{C}$ & 0.12 & 0.05 & 0.14 & 2.44 & $0.016^{*}$ \\
\hline Training $\times \mathrm{I} / \mathrm{C}$ & 0.18 & 0.09 & 0.14 & 1.99 & $0.034^{*}$ \\
\hline Appraisal feedback $\times$ I/C & 0.14 & 0.05 & 0.16 & 2.70 & $0.007^{* *}$ \\
\hline Participation x I/C & 0.13 & 0.05 & 0.15 & 2.45 & $0.015^{\star}$ \\
\hline Autonomy $\times \mathrm{l} / \mathrm{C}$ & 0.17 & 0.06 & 0.19 & 3.09 & $0.002^{\star *}$ \\
\hline
\end{tabular}

$R^{2}=.336 ; F=20.051 ;$ Sig. $F=000$

${ }^{*} p<.05 ;{ }^{* *} p<.01 ;{ }^{* \star *} p<.001$

\section{CONCLUSION}

\section{Implications}

First, appraisal feedback was reported as the HRM practice that most strongly improved individual performance in this study. One explanation for this result is that feedback may be one management strategy to provide opportunities for employees' development because it gives guidelines for the employee's future growth. Appraisal feedback is a direct means to improve communication between the employee and the supervisor in a work unit. Communication may be one management practice that leads to increases in individual performance because it provides the chance for exchanges regarding administrative affairs, including performance and motivation, between 
members and leaders in an organization. Another explanation is that appraisal feedback plays a role in monitoring employee's performance. When their performance is monitored and evaluated by the supervisor, employees are more likely to consider their administrative development. In sum, among the HRM practices studied in this research, appraisal feedback had the most direct impact on individual performance because it is a managerial tool for directly evaluating employees' performance.

Second, the results supported the hypothesis that individualism-collectivism moderates the relationship between HRM practices and individual performance. The results showed that more individualistic orientations are more likely to moderate the relationship. One possible explanation is that HRM practices and individual performance are more likely to be related to personal development. Additionally, as noted in the previous section, almost all HRM practices were originally developed and maintained in private sector organizations and western countries that emphasize individualism. Thus, we can say that employees who have more individualistic orientations are more likely to make use of the practices to increase their performance, as well as to understand the importance of innovative HRM practices in a work unit, even when their nation or organization has been classified as a collectivist culture.

Based on these findings and discussions, some implications can be drawn for practicing managers in public sector organizations. We found that public sector organizations can increase their employees' performance by developing personnel strategies to support innovative HRM practices. Unfortunately, career development failed to increase individual performance in this study, although some studies (e.g., Ospina 1996) have reported a positive relationship between career development and productivity in the public sector. The findings here suggest that managers in public sector organizations need to develop and maintain innovative HRM practices to increase their employees' performance. To be sure, some theories, such as resource-based theory, have consistently argued that human capital may be one force for increasing organizational productivity and performance. Thus, by adopting HRM practices, employees and organizations in the public sector can have opportunities to increase their performance. Second, based on this study's findings about its moderating effect, leaders in organizations need to consider individualism-collectivism when they develop HRM practices. That is, a misfit between managerial tools and cultural orientations can lead to a decrease in individual performance and organizational productivity. Thus, managers need to consider the importance of culture, including personality and organizational culture, when organizations adopt HRM practices. 


\section{Limitations and Future Research}

There are some limitations to this study. First, it may have been influenced by social desirability and common method variance because data were collected through self-reported survey, which can lead to biased responses. For example, participants may have a tendency to report higher levels of individual performance in the processes of self-evaluation. Second, it is important to identify the issue of generalizability. Although this study selected subjects from all ministries in the Korean central government, it was limited to the departments of human resources and public relations in each ministry. Third, this study measured individual performance based on employees' self-perception, which may differ from objective data on individual performance. Additionally, individual performance items (e.g., "I am very competent") may conceptually overlap with other items describing HRM practices (e.g., "I feel involved in important decisions in my work unit"), and it may lead to decreases in the variables' construct validity in this study.

Based on the study's limitations, the following suggestions are presented. First, future research should employ multisource data to reduce the influence of common method bias and social desirability. Future studies need to collect data from multiple sources, including supervisors' evaluations of employee performance. Second, researchers may wish to expand their sampling frame to other public sector organizations, including employees who work in other areas. Third, future studies need to examine whether all items used in this study are appropriately loaded on each construct by using confirmatory factor analysis (CFA). As pointed out in the preceding section, some items are conceptually overlapped. Thus, future researchers should conduct CFAs to verify each construct's validity.

\section{Summary}

Our findings suggested that almost all HRM practices, including training, appraisal feedback, participation in decision-making, and autonomy, positively influence the improvement of individual performance, although career development failed to affect individual performance. Like other studies mainly conducted in private sector organizations, this study concluded that innovative HRM practices are managerial efforts to increase individual performance in public sector organizations. Further, we found that individualism-collectivism had a moderating effect on the relationship between HRM practices and individual performance. It is necessary to consider cultural orientation, including personality and organizational culture, when introducing new management practices in a work unit. The misfit between cultural orientations and managerial 
practices may be one reason for lower individual performance and organizational productivity.

\section{REFERENCES}

Ammons, David N., \& Arnold Rodriguez. (1986). Performance appraisal practices for upper management in city government. Public Administration Review, 46(5): 460-67.

Appelbaum, Eileen, \& Rosemary Batt. (1994). The new American workplace: Transforming work systems in the United States. Ithaca, NY: ILR Press.

Armstrong, Michael, \& Angela Baron. (1998). Performance management: The new realities. London: Institute of Personnel and Development.

Arthur, Jeffrey. B. (1994). Effects of human resource systems on manufacturing performance and turnover. Academy of Management Journal, 37(3): 670-87.

Barney, Jay. (1991). Firm resources and sustained competitive advantage. Journal of Management, 17(1): 99-120.

Becker, Brian, \& Barry Gerhart. (1996). The impact of human resource management on organizational performance: Progress and prospect. Academy of Management Journal, 39(4): 779-801.

Blumberg, Melvin, \& Charles D. Pringle. (1982). The missing opportunity in organizational research: Some implications for a theory of work performance. Academy of Management Review, 7(4): 560-69.

Bowman, James S. (1994). At last, an alternative performance appraisal: Total quality management. Public Administration Review, 54(2): 129-36.

Breaugh, James A. (1985). The measurement of work autonomy. Human Relations, 38(6): 551-70.

Butler, John E., Gerald F. Ferris, \& Nancy K. Napier. (1991). Strategy and human resources management. Cincinnati, $\mathrm{OH}$ : South-Western Publishing.

Cardy, Robert L., \& Gregory H. Dobbins. (1994). Performance appraisal: Alternative perspectives. Cincinnati, OH: South-Western Publishing.

Carroll, Stephen J., \& Allan N. Nash. (1970). Some personal and situational correlates of reactions to management development training. Academy of Management Journal, 13(2): 187-96.

Carson, Kenneth P., Robert L. Cardy, \& Gregory H. Dobbins. (1991). Performance appraisal as effective management or deadly management disease. Group \& Organization Studies, 16(2): 143-59. . (1992). Upgrade the employees evaluation process. HR Magazine 88-92. 
Cipolla, Frank P. (1996). Human resource management in the federal government: A retrospective. The Public Manager: The New Bureaucrat, 25(1): 17-19.

Daley, Dennis M. (1992). Pay for performance, performance appraisal, and total quality management. Public Productivity and Management Review, 16(1): 39-51.

Datta, Deepak K., James P. Guthrie, \& Patrick M. Wright. (2005). Human resource management and labor productivity: Does industry matter? Academy of Management Journal, 48(1): 135-45.

Davis, Keith. (1997). Human behavior at work: Organizational behavior, 5th ed. New York: McGraw-Hill.

Deci, Edward. L., \& Richard M. Ryan. (1985). Intrinsic motivation and self-determination in human behavior. New York: Plenum.

Delaney, John T., \& Mark A. Huselid. (1996). The impact of human resource management practices on perceptions of organizational performance. Academy of Management Journal, 39(4): 949-69.

Dobbins, Gregory H., Robert L. Cardy, \& Kenneth P. Carson. (1991). Examining fundamental assumptions: A contrast of person and system approaches to human resource management. In Gerald R. Ferris and Kendrith M. Rowland (Eds.), Research in personnel and human resource management (vol. 9, pp. 1-38). Greenwich, CT: JAI Press.

Donald, Carrie G., Thomas S. Lyons, \& Rebecca C. Tribbey. (2001). A partnership for strategic planning and management in a public organization. Public Performance \& Management Review, 25(2): 176-93.

Dulebohn, James H., Gerald R. Ferris, \& James. T. Stodd. (1995). The history and evolution of human resource management. In Gerald R. Ferris, Sherman Rosen, and Darold T. Barnum (Eds.), Handbook of human resource management (pp. 18-41). Cambridge, MA: Blackwell.

Earley, P. Christopher, \& Cristina B. Gibson. (1998). Taking stock in our progress on individualism-collectivism: 100 years of solidarity and community. Journal of Management, 24(3): 265-304.

Erez, Miriam, \& P. Christopher Earley. (1993). Culture, self-identity, and work. New York: Oxford University Press.

Fey, Carl F., \& Ingmar Bjorkman. (2001). The effect of human resource management practices on MNC subsidiary performance in Russia. Journal of International Business Studies, 32(1): 59-75.

Gattiker, Urs E. (1995). Firm and taxpayer returns from training of semiskilled employees. Academy of Management Journal, 38(3): 1152-73.

Goldstein, Irwin. L. (1993). Training in organizations: Needs assessment, development, and evaluation, 3rd ed. Monterey, CA: Brooks/Cole. 
Gomez, Carolina, \& Benson Rosen. (2001). The leader-member exchange as a link between managerial trust and employee empowerment. Group \& Organization Management, 26(1): 53-69.

Gould-Williams, Julian. (2003). The importance of HU practices and workplace trust in achieving superior performance: A study of public-sector organizations. International Journal of Human Resource Management, 14(1): 28-54.

Guest, David E. (1997). Human resource management and performance: A review and research agenda. International Journal of Human Resource Management, 8(3): 263-75.

Guthrie, James P. (2001). High-involvement work practices, turnover, and productivity: Evidence from New Zealand. Academy of Management Journal, 44(1): 180-90.

Guthrie, James P., \& Catherine E. Schwoerer. (1994). Individual and contextual influences on self-assessed training needs. Journal of Organizational Behavior, 15(5): 405-22.

Gutteridge, Thomas G. (1986). Organizational career development systems: The state of the practice. In Douglas T. Hall and Associates (Eds.), Career development in organizations (pp. 50-94). San Francisco: Jossey-Bass.

Gutteridge, Thomas G., Zandy B. Leibowitz, \& Jane E. Shore. (1993). Organizational career development. San Francisco: Jossey-Bass.

Hackman, J. Richard, \& Greg. R. Oldham. (1975). Development of the job diagnostic survey. Journal of Applied Psychology, 60: 259-86.

Haines III, Victor Y., Sylvie St-Onge, \& Alexander Marcoux. (2004). Performance management design and effectiveness in quality-driven organizations. Canadian Journal of Administrative Sciences, 21(2): 146-61.

Heilman, Madeline E., Caryn J. Block, \& Jonathan A. Lucas. (1992). Presumed incompetent? Stigmatization and affirmative action efforts. Journal of Applied Psychology, 77(4): 536-44.

Hofstede, Geert. (1980). Culture's consequences: International differences in work related values. Beverly Hills, CA: SAGE Publications.

(1997). Culture and organizations: Software of the mind. New York: McGrawHill.

Hood, Christopher, \& Guy Peters. (2004). The middle aging of new public management: Into the age of paradox? Journal of Public Administration Research and Theory, 14(3): 267-82.

House, Robert K. (1962). An experiment in the use of management training standards. Academy of Management Journal, 5(1): 76-81.

Huselid, Mark A. (1995). The impact of human resource management practices on turnover, productivity, and corporate financial performance. Academy of Manage- 
ment Journal, 38(3): 635-72.

Huselid, Mark A., Susan E. Jackson, \& Randall S. Schuler. (1997). Technical and strategic human resource management effectiveness as determinants to firm performance. Academy of Management Journal, 40(1): 171-88.

Ichniowski, Casey, \& Kathryn Shaw. (1999). The effects of human resource management systems on economic performance: An international comparison of U.S. and Japanese plants. Management Science, 45(5): 704-21.

Jackson, Susan E., \& Randall S. Schuler. (1995). Understanding human resource management in the context of organizations and their environments. Annual Review of Psychology, 46: 237-64.

Kearney, Richard C., \& Steven W. Hays. (1994). Labor-management relations and participative decision making: Toward a new paradigm. Public Administration Review, 54(1): 44-51.

Kim, Soonhee. (2002). Participative management and job satisfaction: Lessons from management leadership. Public Administration Review, 62(2): 231-41.

Lam, Simon S. K., \& John Schaubroeck. (1998). Total quality management and performance appraisal: An experimental study of versus results and group versus individual approaches. Journal of Organizational Behavior, 20: 445-57.

Lawler, Edward. E. (1992). Employee involvement and total quality management. San Francisco: Jossey-Bass.

Lawler, Edward E., \& J. Richard Hackman. (1969). Impact of employee participation in the development of pay incentive plans. Journal of Applied Psychology, 53(6): 467-71.

Leung, Kwok. (1987). Some determinants of reactions to procedural models for conflict resolution: A cross-national study. Journal of Personality and Social Psychology, 53(5): 898-908.

Liden, Robert C., \& Thomas W. Tewksbury. (1995). Empowerment and work teams. In Gerald F. Ferris, Sherman Rosen, and Darold T. Barnum (Eds.), Handbook of human resource management (pp. 386-403). Cambridge, MA: Blackwell.

London, Manuel, \& Stephen A. Stumpf. (1986). Individual and organizational career development in changing times. In Douglas T. Hall and Associates (Eds.), Career development in organization (pp. 21-49). San Francisco: Jossey-Bass.

Lowin, Aaron. (1968). Participative decision making: A model, literature critique, and prescriptions for research. Organizational Behavior and Human Performance, 3(1): 68-106.

Lynn, Laurence E. (2001). The myth of the bureaucratic paradigm: What traditional public administration really stood for. Public Administration Review, 61(2): 144-60. 
MacDuffie, John P. (1995). Human resource bundles and manufacturing performance: Organizational logic and flexible production system in the world auto industry. Industrial and Labor Relations Review, 48(2): 197-221.

Maier, Norman R. F. (1955). Psychology in industry, 2nd ed. Boston: Houghton-Mifflin.

Marrow, Alfred J., David G. Bowers, \& Stanley E. Seashore. (1967). Management by participation: Creating a climate for personal and organizational development. New York: Harper \& Row.

McCaffrey, David P., Sue R. Faerman, \& David W. Hart. (1995). The appeal and difficulties of participative systems. Organization Science, 6(6): 603-27.

Miller, Joan. G., David M. Bersoff, \& Robin L. Harwood. (1990). Perception of social responsibilities in India and the United States: Moral imperatives or personal decisions? Journal of Personality and Social Psychology, 58(1): 33-47.

Miller, Katherine I., \& Peter R. Monge. (1986). Participation, satisfaction, and productivity: A meta-analytic review. Academy of Management Journal, 29(4): 727-53.

Molander, Christopher, \& Jonathan Winterton. (1994). Managing human resources. London: Routledge.

Mount, Michael K. (1984). Satisfaction with a performance appraisal system and appraisal discussion. Journal of Organizational Behavior, 5: 271-79.

Murphy, Kevin R., \& Jeanette N. Cleveland. (1995). Understanding performance appraisal: Social organizations, and goal-based perspectives. Thousand Oaks, CA: Sage.

Ngo, Hang-Yue, Daniel Turban, Chung-Ming Lau, \& Siu-yun Lui. (1998). Human resource practices and firm performance of multinational corporations: Influences of country origin. International Journal of Human Resource Management, 9(4): 632-52.

Noe, Raymond A. (1996). Is career management related to employee development and performance? Journal of Organizational Behavior, 17(2): 119-33.

Nyhan, Ronald C. (1994). The interrelationships of organizational commitment, trust and participatory decision-making practices in public organizations. Unpublished Ph.D. dissertation, Florida Atlantic University.

Ospina, Sonia M. (1996). Illusions of opportunity: Employee expectations and work place inequality. Ithaca, NY: Cornell University Press.

Parker, Sharon, K., \& Nick Turner. (2002). Work design and individual work performance: Research findings and an agenda for future inquiry. In Sabine Sonnentag (Eds.), Psychological management of individual performance (pp. 69-93). New York: John Wiley and Sons.

Perry, James L., Beth Ann Petrakis, \& Theodore K. Miller. (1989). Federal merit pay, round II: An analysis of the performance management and recognition system. 
Public Administration Review, 49(1): 29-37.

Pfeffer, Jeffrey. (1994). Competitive advantage through people. Boston: Harvard Business School Press.

Pynes, Joan E. (1997). Human resources management for public and nonprofit organizations. San Francisco: Jossey-Bass.

. (2004). Human resources management for public and nonprofit organizations, 2nd ed. San Francisco: Jossey-Bass.

Quinn, Robert. E., \& Gretchen M. Spreitzer. (1997). The road to empowerment: Seven questions every leader should consider. Organizational Dynamics, 26(2): 37-49.

Ramamoorthy, Nagarajan, \& Stephen J. Carroll. (1998). Individualism/collectivism orientations and reactions toward alternative human resource management practices. Human Relations, 51(5): 571-88.

Ramamoorthy, Nagarajan, \& Patrick C. Flood. (2004). Individualism/collectivism, perceived task interdependence and teamwork attitudes among Irish blue-collar employees: A test of the main and moderating effects. Human Relations, 57(3): 347-66.

Rosenberg, Richard D., \& Eliezer Rosenstein. (1980). Participation and productivity: An empirical study. Industrial and Labor Relations Review, 33(3): 355-67.

Rosenzweig, Philip M., \& Nitin Nohria. (1994). Influences on human resource management practices in multinational corporations. Journal of International Business Studies, 25(2): 229-51.

Rousseau, Denise. M. (1995). Psychological contracts in organizations: Understanding written and unwritten agreement. Thousand Oaks, CA: SAGE Publications.

Sagie, Abraham, \& Meni Koslowsky. (2000). Participation and empowerment in organizations: Modeling, effectiveness, and applications. Thousand Oaks, CA: Sage Publications, Inc.

Schuler, Randall S. (1984). Personnel and human resource management, 2nd ed. St. Paul, MN: West Publishing Company.

Selden, Sally Coleman, Patricia Wallace Ingraham, \& Willow Jacobson. (2001). Human resource practices in state government: Findings from a national survey. Public Administration Review, 61(5): 598-607.

Shaw, Jason D., John E. Delery, G., G. Douglas Jenkins, Jr., \& Nina Gupta. (1998). An organization-level analysis of voluntary and involuntary turnover. Academy of Management Journal, 41(5): 511-25.

Smith, Catherine A. (1995). Human resource practices and policies as antecedents of organizational commitment. Unpublished Ph.D. dissertation, University of Western Ontario, London, Ontario, Canada.

Sonnentag, Sabine, \& Michael Frese. (2002). Performance concepts and performance 
theory. In Sabine Sonnentag (Eds.), Psychological management of individual performance (pp. 3-26). New York: John Wiley and Sons.

Spreitzer, Gretchen M. (1995). An empirical test of comprehensive model of intrapersonal empowerment in the workplace. American Journal of Community Psychology, 23(5): 601-29.

Spreitzer, Gretchen. M., Suzanne C. De Janasz, \& Robert E. Quinn. (1999). Empowered to lead: The role of psychological empowerment in leadership. Journal of Organizational Behavior, 20(4): 511-26.

Stark, Andrew. (2002). What is the new public management? Journal of Public Administration Research and Theory, 12(1): 137-51.

Steijn, Bram. (2004). Human resource management and job satisfaction in the Dutch public sector. Review of Public Personnel Administration, 24(4): 291-303.

Tannenbaum, Scott. I., John E. Mathieu, Eduardo Salas, \& Janis A. Cannon-Bowers, J. A. (1991). Meeting trainees' expectations: The influence of training fulfillment on the development of commitment, self-efficacy, and motivation. Journal of Applied Psychology, 76(6): 759-69.

Ting, Yuan. (1996). Analysis of job satisfaction of the federal white-collar work force: Findings from the survey of federal employees. American Review of Public Administration, 26(4): 439-56.

Triandis, Harry C. (1995). Individualism and collectivism. Boulder, CO: Westview Press.

Triandis, Harry C., Christopher McCusker, \& Harry Hui. (1990). Multimethod probes of individualism and collectivism. Journal of Personality and Social Psychology, 59(5): 1006-20.

Triandis, Harry C., \& Eunkook M. Suh. (2002). Cultural influences on personality. Annual Review of Psychology, 53:133-60.

Wagner, John A. (1994). Participation's effects on performance and satisfaction: A reconsideration of research evidence. Academy of Management Review, 19(2): 312-30.

Wall, Toby D., John L. Cordery, \& Chris W. Clegg. (2002). Empowerment, performance, and operational uncertainty: A theoretical integration. Applied Psychology: An International Review, 51(1): 146-69.

Wexley, Kenneth N., \& Gary P. Latham. (1991). Developing and training human resources in organizations. New York: HarperCollins.

Wexley, Kenneth N., \& Gary A. Yukl. (1984). Organizational behavior and personnel psychology. Homewood, IL: Irwin.

Workman, Michael. (2001). Collectivism, individualism, and cohesion in team-based occupation. Journal of Vocational Behavior, 58(1): 82-97. 
Wright, Bradley E., \& Soonhee Kim. (2004). Participation's influence on job satisfaction: The importance of job characteristics. Review of Public Personnel Administration, 24(1): 18-40.

Wright, Patrick M., \& Gary C. McMahan. (1992). Theoretical perspectives for strategic human resource management. Journal of Management, 18(2): 295-320.

Wright, Patrick M., Gary C. McMahan, \& Abagail McWilliams. (1994). Human resources and sustained competitive advantage: A resource-based perspective. International Journal of Human Resource Management, 5(2): 301-26. 